\title{
HEAT LOSS IN ONE DAY OLD PULLETS INSIDE A HATCHERY
}

\section{IRENILZA DE A. NÄÄS ${ }^{1}$, DANIELA E. GRACIANO ${ }^{2}$, RODRIGO G. GARCIA ${ }^{3}$, MAYARA R. DE SANTANA ${ }^{4}$, DIEGO P. NEVES ${ }^{5}$}

\begin{abstract}
After hatching, pullets are transported to brooding area and vaccinated. One day old chicks have not already developed thermoregulation ability; thus, brooding temperature variations may affect pullet quality leading to broiler meat production losses. This research aimed to calculate sensible heat loss in one day old pullets in hatching area and vaccination room. Ten one day old pullets were randomly selected from hatching area of a commercial hatchery. Infrared images were used to calculate bird surface temperature. Exposure areas for the two conditions were quantified, and both air temperature and wind speed was recorded. Total sensible heat loss was calculated as heat loss by radiation plus heat loss by convection. It was found that heat transfer occurs in different ways at different bird body parts. Total heat loss found for hatching baskets was equivalent to $0.81 \mathrm{~J} \mathrm{~s}^{-1}$ while for vaccination room was $1.16 \mathrm{~J} \mathrm{~s}^{-1}$. Pullet nutrition is based on energy loss from brooding to farm, and the overall pullet heat loss from hatchery to farm accepted is $13.95 \mathrm{~J} \mathrm{~s}^{-1}$. Thus, "starter feed" has relevant excess of energy input. These findings indicate that less energy can be used in initial feed, once heat loss is lower than assumed nowadays. Improved knowledge on these conditions may enhance broiler farm feeding strategies and economics during first rearing week.
\end{abstract}

KEYWORDS: sensible heat, post-hatching, infrared thermography.

\section{PERDA DE CALOR EM PINTAINHOS DE UM DIA EM INCUBATÓRIO}

RESUMO: Após o nascimento, pintainhos são transportados para a sala de pintos e vacinados. Pintainhos de um dia ainda não desenvolveram a habilidade de termorregulação, portanto a variação da temperatura na sala de pintos pode afetar a qualidade dos pintainhos, levando a perdas na produção de carne de frangos de corte. Esta pesquisa visou a calcular a perda de calor sensível em pintos de um dia, na sala de pintos e na de vacinação. Dez pintainhos de um dia foram selecionados ao acaso na área de nascimento de um incubatório comercial. Foram utilizadas imagens termográficas infravermelho, para calcular a temperatura superficial das aves. As áreas de exposição das aves foram quantificadas nos dois ambientes, e ambas as temperatura e a velocidade do ar foram registradas. A perda de calor sensível total foi calculada como o calor perdido por radiação somado à perda de calor por convecção. Foi encontrado que a transferência de calor ocorre em diferentes formas, nas várias partes do corpo da ave. A perda de calor total encontrada nas cestas do nascedouro era equivalente a $0,81 \mathrm{~J} \mathrm{~s}^{-1}$, enquanto na área de vacinação foi de $1,16 \mathrm{~J} \mathrm{~s}^{-1}$. A nutrição de pintainhos é baseada na energia perdida desde o nascimento até a chegada à granja e, geralmente é aceito o valor de 13,95 $\mathrm{J} \mathrm{s}^{-1}$, como um valor total de perda de calor do incubatório até a granja; portanto, a ração inicial de pintainhos tem um valor excessivo de insumo de energia. Estes resultados indicam que menos energia poderia ser usada na ração inicial, uma vez que a perda de calor é menor do que a assumida hoje. Conhecimento mais preciso destes valores pode melhorar a estratégia de arraçoamento na primeira semana de criação e a economia de criadores de frangos de corte.

PALAVRAS-CHAVE: calor sensível, pós-eclosão, termografia infravermelho.

\footnotetext{
${ }^{1}$ Eng $^{\underline{a}}$ Civil, Pesquisador Visitante Sênior PVNS-CAPES, Faculdade de Ciências Agrárias - UFGD, Dourados - MS, Brasil, irenilza@gmail.com

${ }^{2}$ Bióloga, M.Sc. em Zootecnia, Faculdade de Ciências Agrárias - UFGD, Dourados - MS, Brasil, danielagraciano@hotmail.com

${ }^{3}$ Zootecnista, Prof. Doutor, Faculdade de Ciências Agrárias - UFGD, Dourados - MS, Brasil, rodrigogarcia@ufgd.edu.br

${ }^{4}$ Zootecnista, M.Sc. em Zootecnia, Faculdade de Ciências Agrárias - UFGD, Dourados - MS, Brasil.

${ }^{5}$ Desenhista Industrial, M.Sc. em Engenharia Agrícola, Faculdade de Engenharia Agrícola-UNICAMP, Campinas - SP, Brasil.

Recebido pelo Conselho Editorial em: 8-5-2013
}

Aprovado pelo Conselho Editorial em: 9-1-2014 


\section{INTRODUCTION}

Cold brooding temperatures $\left(<28^{\circ} \mathrm{C}\right)$ have previously been shown to decrease broiler growth compared to standard $\left( \pm 30^{\circ} \mathrm{C}\right)$ or high $\left(>32^{\circ} \mathrm{C}\right)$ and the ideal relative humidity conditions $(50 \%)$ (BAARENDSE et al., 2006; LEKSRISOMPONG et al., 2009). Post-hatching temperature is considered a physical factor that has major contribution on broiler performance affecting feed intake, weight gain, and conversion rate (BAARENDSE et al., 2006; AKŞIT et al., 2010; BARACHO et al., 2010; CORDEIRO et al., 2010). In birds under heat stress, metabolic modifications are observed, associated with biochemical and hematological variations (NITSAN et al, 1991). After hatching, chicks are highly sensible to thermal changes and microorganism attack, and a good management decision is to rapidly move them from hatchery to brooding area, adopting environmental control and more appropriate temperature and relative humidity. When kept at hatchery for more than 72 hours, they begin to dehydrate and could perish (BARACHO et al., 2010).

Many other factors are related to the good management of hatcheries such as fertile eggs storage, temperature and humidity control inside hutch box, good hatchery and brooding environmental control, in order to keep pullet quality warranting better performance during the first rearing weeks (CARDOSO, 2009).

Positive results in broiler performance (feed intake, weight gain, and conversion rate) are affected by thermal control where flocks are reared, the most happen due to unbalanced heat loss between bird and environment (SOUZA et al., 2010). Broilers need to be reared from hatch to slaughter within thermal neutral zone to reach production efficiency (CORDEIRO et al., 2010). When pullets are exposed to heat stress or other disturbance such as transportation from brooding area to farm, they may get sick affecting flock productivity (CAMARGO, 2011).

Infrared thermal imaging is a non-invasive method of measuring radiant heat emitted from surfaces. This technology has been used in many applications, including determining human and animal skin surface temperatures (NÄÄS et al., 2010; NASCIMENTO et al., 2011a, b; HAUVIK \& MERCER, 2012). It is generally accepted that thermal patterns on skin are related to skin blood perfusion (HAUVIK \& MERCER, 2012). Blood flow differences on skin surface are important for thermoregulation, and varies when environment temperature changes to maintain homeostasis (YAHAV et al., 2004; FERREIRA et al., 2011; EDGAR et al., 2013). This shows the potential of using thermal images to infer heat exchange and thermal comfort.

This research aimed to estimate surface temperature difference and to calculate sensible heat loss in one day old pullets after hatching in brooding and vaccination area within a commercial hatchery.

\section{MATERIAL AND METHODS}

The experiment was carried out in a commercial hatchery located in Amparo, SP, Brazil (latitude $22^{\circ} 42^{\prime} 04^{\prime \prime} \mathrm{S}$, longitude $46^{\circ} 45^{\prime} 52^{\prime \prime} \mathrm{W}$ at $674 \mathrm{~m}$ altitude), from January to February. Regional climate according to Köeppen classification is Cwa type (temperate and humid climate with dry winter and hot summer); average daily temperature during trial was above $22{ }^{\circ} \mathrm{C}$. Procedures were followed as hatchery daily routine.

Ten pullets (Cobb ${ }^{\circledR}, 1$ day old) were randomly selected from a 100 pullet box in commercial multiple-stage incubation just after hatching. They were in good physical condition, had no plumage damage and had been exposed to minimal handling during study. Subsequently being separated from flock, they were marked upside head with appropriate ink for identification. After trial, they were delivered back to the farm.

Chick surface thermal image was obtained using an infrared camera (Testo ${ }^{\circledR}$ 880) (Figure $1 \mathrm{~A}$ ), with $\pm 0.1^{\circ} \mathrm{C}$ accuracy at approximately $0.50 \mathrm{~m}$ distance from target. Flock homogeneity was checked from surface temperature distribution profile (Figure 1B) by using Testo IRSoft ${ }^{\circledR}$ software. 


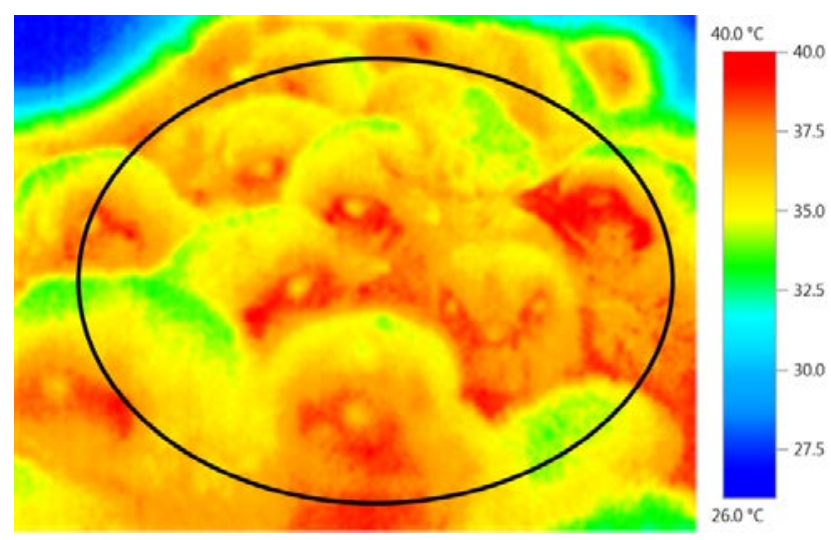

A

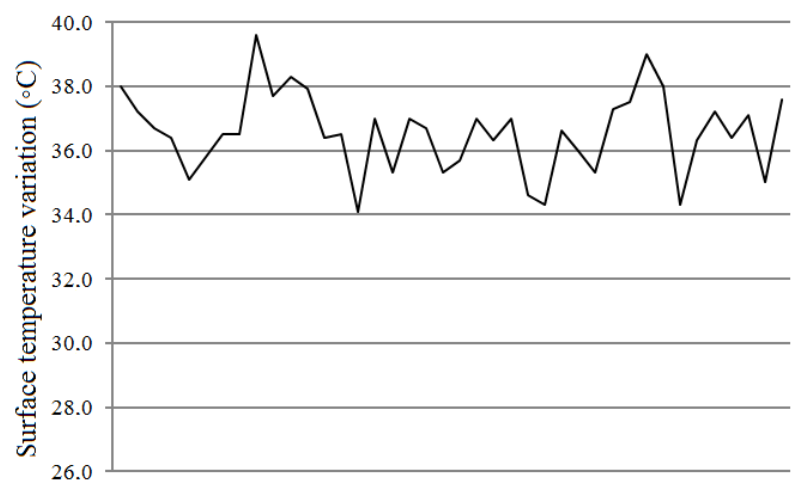

B

FIGURE 1. Post hatch pullet thermographic image (A), and surface temperature distribution of grouped birds (maximum surface temperature $=39.6^{\circ} \mathrm{C}$; average surface temperature $=36.6{ }^{\circ} \mathrm{C}$, and minimum surface temperature $=34.1^{\circ} \mathrm{C}$; standard deviation $=1.2^{\circ} \mathrm{C}$ ).

Next group imaging (10 images) in hatchery area, birds were taken to vaccination room where new thermal images (10 images) were recorded (Figure 2 ) at $0.50 \mathrm{~m}$ distance from target. Through Testo IRSoft ${ }^{\circledR}$ software, 10 points were marked within thermal image in each body part (head, trunk, and legs - Figure 2) and average surface temperature calculated. By the means of a data logger $\mathrm{HTA}^{\circledR}$ with accuracy of $\pm 0.1^{\circ} \mathrm{C}$, environment temperature and air speed were recorded. Surface temperature variation was calculated for both studied conditions. And field trial lasted for approximately 15 minutes.

To estimate bird heat losses, surface area (A) was calculated based on sum of the most suitable geometric forms for a bird. Head was considered a sphere, trunk an oval shape, and legs as cylinders (Figure $2 \mathrm{~A}, \mathrm{~B}$ ). Total sensible heat loss (Qst) was measured as the sum of the heat losses by radiation (Qr), and convection (Qc) according to YAHAV et al. (2004). Conduction heat losses to the floor were neglected by the authors as feet contact area is relatively smaller than the rest of the body. Qr and Qc were calculated using Equations 1 and 2 (MEIJERHOF \& VAN BEEK, 1993; YAHAV et al., 2004).

$$
\begin{aligned}
& Q r=\varepsilon \sigma A\left(T s^{4}-T a^{4}\right) \\
& Q c=h A(T s-T a)
\end{aligned}
$$

where,

Qr - radiation heat loss $\left(\mathrm{J} \mathrm{s}^{-1}\right)$;

Qc - convection heat loss $\left(\mathrm{J} \mathrm{s}^{-1}\right)$;

$\varepsilon$ - skin and plumage emissivity;

$\sigma$ - Stefan Boltzmann constant (5.67 $\left.10^{-8} \mathrm{~J} \mathrm{~s} \mathrm{~m}^{-2} \mathrm{~K}^{-4}\right)$;

$\mathrm{h}$ - convection coefficient (15 $\mathrm{J} \mathrm{s} \mathrm{m}^{-2 \circ} \mathrm{C}$; MEIJERHOF \& VAN BEEK, 1993);

A - bird surface area $(\mathrm{m})$;

Ts - bird surface temperature $\left({ }^{\circ} \mathrm{C}\right)$; and

Ta - air temperature $\left({ }^{\circ} \mathrm{C}\right)$.

The used emissivity coefficient $(\varepsilon)$ was 0.94 for pullets, which is within the emissivity range for biological material. There are several values adopted in literature, among them CANGAR et al. 
(2008) suggested the overall emissivity value of 0.95 for broilers, and MALHEIROS et al. (2000) used 0.94 for post-hatch chicks.
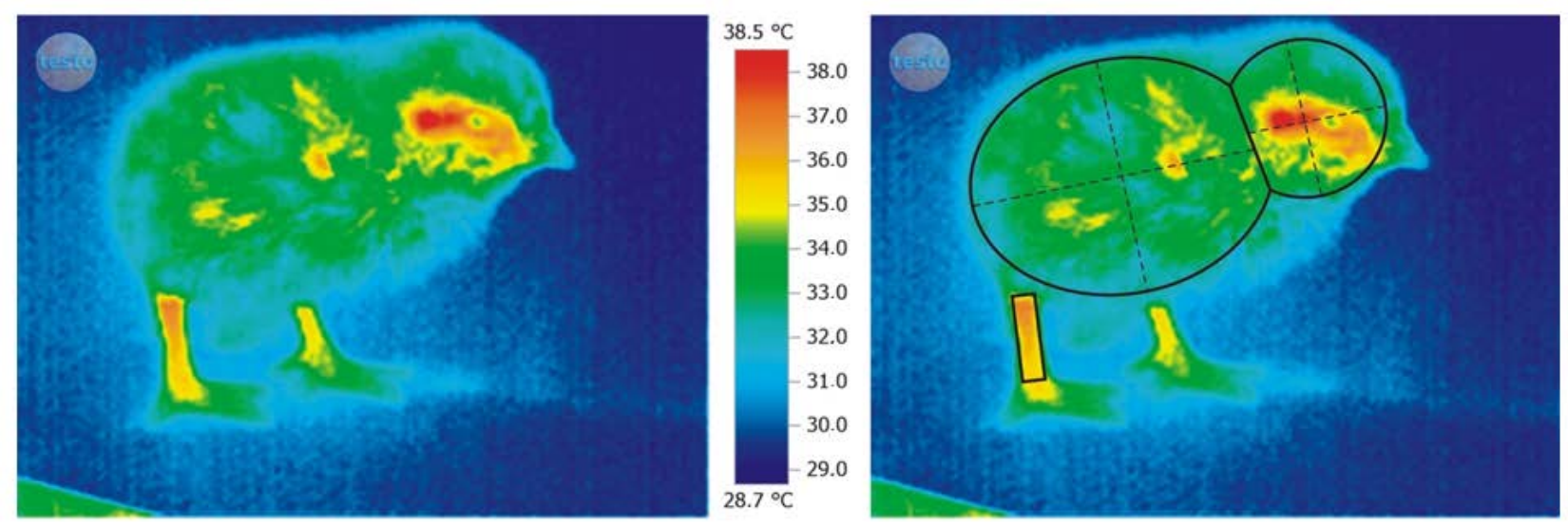

A
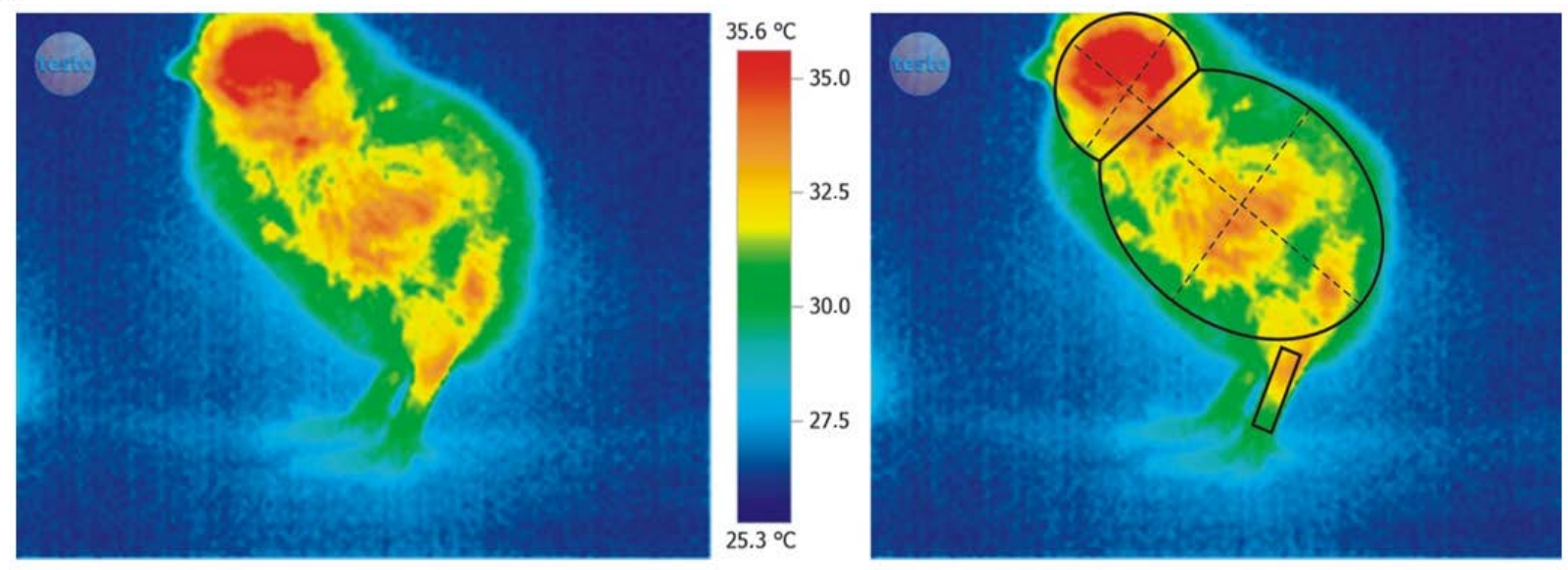

B

FIGURE 2. Pullet infrared thermal image at hatchery (A), and at vaccination room (B) and bird surface area estimation scheme.

Heat losses were separately calculated for each bird using each area first, and then added each part heat loss resulting in total heat loss. Average surface temperatures of all birds were calculated and environment temperature recorded. Tukey test was applied for average values, and comparison processed using 95\% of confidence interval.

\section{RESULTS AND DISCUSSION}

Hatchery environment temperature was $28.9 \pm 0.2^{\circ} \mathrm{C}$, and sensible heat loss was $0.81 \pm 0.1 \mathrm{~J} \mathrm{~s}^{-1}$; while in vaccination room had $25.5 \pm 0.2^{\circ} \mathrm{C}$ environment temperature, and $1.16 \pm 0.1 \mathrm{~J} \mathrm{~s}^{-1}$ heat loss. Considering displacement time of near $5 \mathrm{~min}(300 \mathrm{~s})$, heat loss by each bird is close to $300 \mathrm{~J}$. The adopted feed energy threshold by ration formulation was $13.95 \mathrm{~J} \mathrm{~s}^{-1}$ (AKŞIT et al., 2010). This value is assumed considering pullet reaching farm in around 86,400 s (1 day). However, calculated heat loss average is almost ten times smaller than threshold, which may infer that there might be an energy excess in initial feed ration to recover birds from heat loss that is, actually, less than the assumed value. Considering energy as the highest cost in feed ration, precise calculations may help initial feed cost (TZSCHENTKE \& PLAGEMAN, 2006).

In the other hand, the heat loss calculation was affected by increased temperature in pullet head due to physical reactions to vaccination, which increased its surface temperature. Vaccination 
against Marek in hatchery is mandatory, and most hatcheries also vaccinate pullets against other epidemic diseases (LAUVERS \& FERREIRA, 2011; MATEUS \& SANTOS, 2011).

Bird body parts may contribute differently in heat losses and should be classified according to vascularization or feathering as pointed out by ABREU et al. (2012). Heat loss to rearing environment is related to bird surface temperature consisting on sum of each part heat loss. The less feathered or non-feathered parts might promote higher sensible heat loss (NASCIMENTO et al., 2011a). In the present study, sensible heat loss differed for each pullet body part $(p<0.05)$ (Figure 3). In hatching area, the highest heat loss occurred in legs (129.2 $\left.\mathrm{J} \mathrm{s} \mathrm{m}^{-2}\right)$; while in vaccination room, the highest sensible heat loss occurred for head $\left(176.8 \mathrm{~J} \mathrm{~s} \mathrm{~m}^{-2}\right)$. That probably is due to inflammatory process from vaccination. Besides that, vaccination room temperature was lower than hatchery, increasing sensible heat loss from bird (NEVES et al., 2009).

Trunk, which is the largest body part, contributed with $99.5 \%$ to total heat loss, when considering each pullet body part as expected.
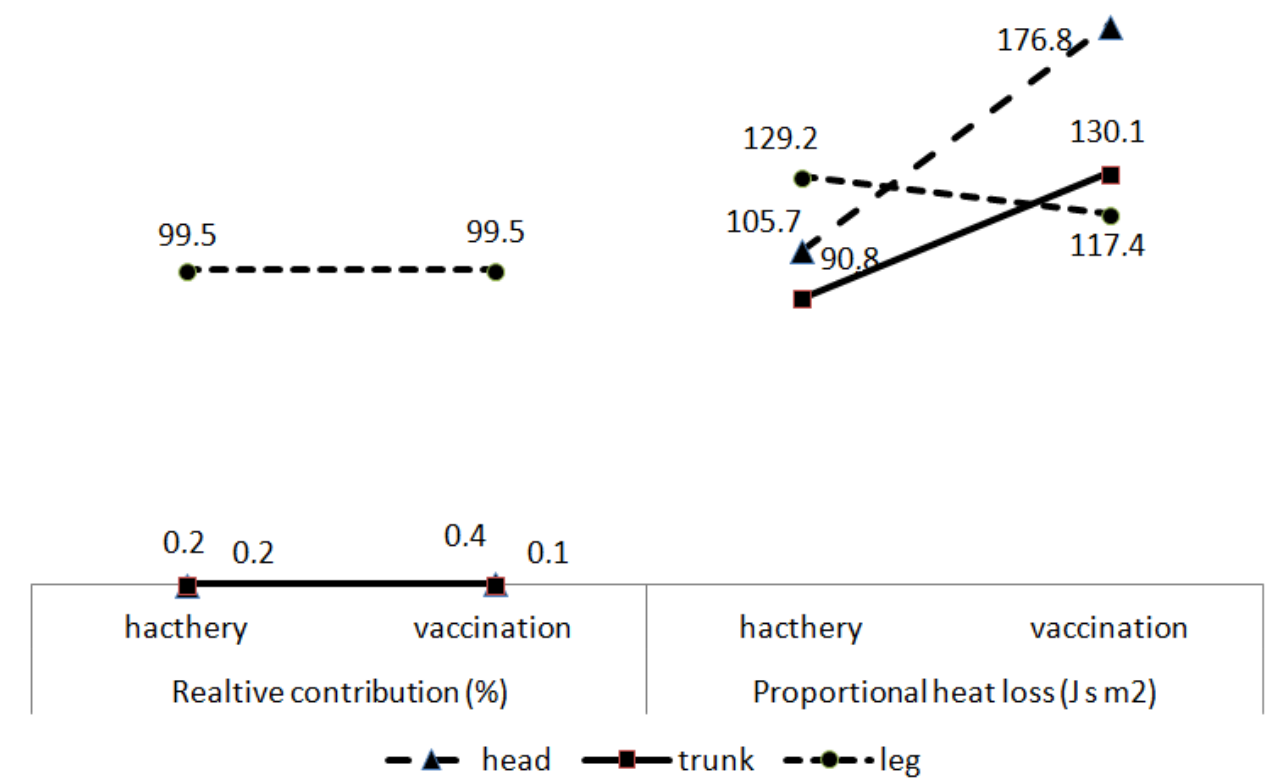

FIGURE 3. Pullet body parts contribution to heat loss and total sensible heat loss (head, trunk and legs).

Total heat loss average was of $0.98 \mathrm{~J} \mathrm{~s}^{-1}$ for both environments. This value effect in larger displacement times from hatchery to farm can be harmful to pullets. YAHAV et al. (2004) found that thermal unbalance in rearing conditions could affect metabolism and consequently performance. Nowadays, pullet heat loss is estimated and then recovered through diet with a baseline of $0.23 \mathrm{~J} \mathrm{~s}^{-1}$; representing 3,489 $\mathrm{J} \mathrm{s}^{-1}$ of metabolic energy per kg of initial feed ration.

Chicks survive the first days using egg residual nutrients (HAYASHI, 2011), which respond by $50 \%$ of their energy needs and $43 \%$ of needed protein (VIEIRA, 2004). While $80 \%$ egg fat is used by pullets in the first day, proteins take more time to be uses (NITSAN et al., 1991). Therefore, if pullets are reared in farm close to hatchery, there is no need to use high initial feed ration energy, i.e. using same feed ration energy dosage apart from transportation distance must lead to cost waste.

High accuracy estimates of pullet heat loss will help to calculate a proper energy amount to recover losses inside hatchery until farm delivery (FERREIRA et al., 2011; NEVES et al., 2009). Using surface temperature through thermal images was possible to estimate sensible heat loss in a stationary condition, which could be inferred when movement time is known. These results may allow a better feeding strategy during broiler production. 


\section{CONCLUSION}

Thermal image use allowed estimating sensible heat loss for one day old pullets, which was lower than the threshold adopted by broiler industry. Differences in heat loss amount were found by each pullet body part.

\section{REFERENCES}

ABREU, P.G.; ABREU, V.M.N.; COLDEBELLA, A.; HASSAMER, M.J.; TOMAZELLI, I.L. Medidas morfológicas em função do peso e da idade da ave, por meio de imagens. Revista Brasileira de Engenharia Agrícola e Ambiental, Campinas Grande, v.16, n.7, p.795-801, 2012.

AKŞIT M; YALÇIN S.; YENISEY C.; OZDEMIR D. Brooding temperatures for chicks acclimated to heat during incubation: effects on post-hatch intestinal development and body weight under heat stress. British Poultry Science, Bristol, v.51, n.3, p. 444-452, 2010.

BAARENDSE, P. J. J.; KEMP, B.; VAN DEN BRAND, H. Early age housing temperature affects subsequent broiler chicken performance. British Poultry Science, Bristol, v. 47, n. 2, p.125-130, 2006.

BARACHO, M.S.; NÄÄS, I.A.; GIGLI, A.C.S. Impacto das variáveis ambientais em incubatório de estágio múltiplo de frangos de corte. Engenharia Agrícola, Jaboticabal, v.30, n.4, p.563-577, 2010.

CAMARGO, J.R. Ambiência pré-porteira: o tempo de espera no incubatório e sua influência sobre o desempenho inicial de frangos de corte. 2011. 98 f. Dissertation (Master in Biossystems Engineering) - Escola Superior de Agricultura “Luiz de Queiroz”, Universidade de São Paulo, Piracicaba, 2011.

CANGAR, O.; AERTS, J.M.; BUYSE, J.; BERCKMANS, D. Quantification of the spatial distribution of surface temperatures of broilers. Poultry Science, Champaign, v. 87, n.4, p. 24932499, 2008.

CARDOSO, A.L.S.P. Avaliação da qualidade sanitária de incubatório por meio de placas de sedimentação. Arquivos do Instituto Biológico, São Paulo, v.76, n.2, p.279-283, 2009.

CORDEIRO, M. B.; TINÔCO, I. F. F.; SILVA, J. N.; VIGODERIS, R. B.; PINTO, F. A. C.; CECON, P. R. Conforto térmico e desempenho de pintos de corte submetidos a diferentes sistemas de aquecimento no período de inverno. Revista Brasileira de Zootecnia, Viçosa-MG, v. 39, n.1, p.217-224, 2010.

EDGAR, J. L.; NICOL, C.J.; PUGH, C.A.; PAUL, E.S. Surface temperature changes in response to handling in domestic chickens. Physiology \& Behavior, Elmsford, v. 119, n. 2, p.195-200, 2013.

FERREIRA, V.M.O.S.; FRANCISCO, N.S.; BELLONI, M.; AGUIRRE, G.M.Z.; CALDARA, F.R.; NÄÄS, I.A.; GARCIA, R.G.; ALMEIDA PAZ, I.C.L.; POLYCARPO, G.V. Infrared thermography applied to the evaluation of metabolic heat loss of chicks fed with different energy densities. Brazilian Journal of Poultry Science, Campinas, v.13, n.2, p.113-118, 2011.

HAUVIK, L. E.; MERCER, J.B. Thermographic mapping of the skin surface of the head in baldheaded male subjects. Journal of Thermal Biology, Amsterdam, v.37, n.7, p. 510-516, 2012.

HAYASHI, R.M. Estudo do sistema imunológico e do trato gastrintestinal de frangos de corte nascidos em diferentes períodos em uma mesma incubadora. 2011. 89 f. Dissertação (Mestrado) Universidade Federal do Paraná, Curitiba, 2011.

LAUVERS, G.; FERREIRA, V.P.A. Fatores que afetam a qualidade dos pintos de um dia, desde a incubação até recebimento na granja. Revista Científica Eletrônica de Medicina Veterinária, Curitiba, v. 9, n. 16, p. 1-19, 2011. 
LEKSRISOMPONG, N.; ROMERO-SANCHEZ, H.; PLUMSTEAD, P.W.; BRANNAN, K. E.; YAHAV, S.; BRAKE, J. Broiler incubation. 2. Interaction of incubation and brooding temperature on broiler chick feed consumption and growth. Poultry Science, Champaign, v. 88, n.6, p.13211329, 2009.

MALHEIROS, R.D.; MORAES, V.M.B.; BRUNO, L.D.G.; MALHEIROS, E.B.; FURLAN, R.L.; MACARI, M. Environmental temperature and cloacal and surface temperatures of broilers chicks in first week post hatch. Journal of Applied Poultry Research, Champaign, v.9, n.2, p. 111-117, 2000.

MATEUS, M.C.; SANTOS, J.M.G. Imunização em frangos de corte. Revista em Agronegócios e Meio Ambiente, Palotina, v.4, n.2, p. 227-246, 2011.

MEIJERHOF, R.; VAN BEEK G. Mathematical modeling of temperature and moisture of hatching eggs. Journal of Theoretical Biology, Amsterdan, v.165, n.4, p.27-41, 1993.

NÄÄS, I. A.; ROMANINI, C. E. B.; NEVES, D. P.; NASCIMENTO, G. R; VERCELLINO, R. A. Broiler surface temperature distribution of 42 day old chickens. Scientia Agricola, Piracicaba, v.67, n.5, p. 497-502, 2010.

NASCIMENTO, G.R.; NÄÄS, I. A.; PEREIRA, D. F.; BARACHO, M. S.; GARCIA, R. Assessment of broiler surface temperature variation when exposed to different air temperatures. Brazilian Journal of Poultry Science, Campinas, v. 13, n.4, p. 259-263, 2011 a.

NASCIMENTO, G.R.; PEREIRA, D.F.; NÄÄS, I.A.; RODRIGUES, L.H.A. Índice fuzzy de conforto térmico para frangos de corte. Engenharia Agrícola, Jaboticabal, v.31, n.2, p. 219-229 2011 b.

NEVES, D.P.; ROMANINI, C.E.B.; NASCIMENTO, G.R.; NÄÄS, I.A.; MENEZES, A.G. Estimativa da perda de calor em pintos de um dia dentro do incubatório. In: CONGRESSO BRASILEIRO DE ENGENHARIA AGRÍCOLA, 38., 2009, Juazeiro. Anais... Jaboticabal: Associação Brasileira de Engenharia Agrícola, 2009. 1 CD-ROM.

ITSAN, Z.; EN-AVRAHAM, G.; ZOREF, Z.; NIR, I. Growth and development of digestive organs and some enzymes in broiler chicks after hatching. British Poultry Science, Bristol, v. 32, p. 23-515, 1991.

SOUZA, V. L. F.; BURANELO, G. S.; GASPARINO, E.; CARDOZO, R. M.; BARBOSA, M.J.B. Efeito da automatização nas diferentes estações do ano sobre os parâmetros de desempenho, rendimento e qualidade da carne de frangos de corte. Acta Scientiarum- Animal Sciences, Maringá, v. 32, n. 2, p. 175-181, 2010.

TZSCHENTKE, B.; PLAGEMANN, A. Imprinting and critical periods in early development. World's Poultry Science Journal, Cambridge, v. 62, n.4, p. 626-637, 2006.

VIEIRA, S.L. Digestão e utilização de nutrientes após a eclosão de frangos de corte. In: SIMPÓSIO BRASIL SUL DE AVICULTURA, 5., 2004, Chapecó. Anais...p.26-41.

YAHAV, S.; STRASCHNOW, A.; LUGER, D.; SHINDER, D.; TANNY, J.; COHEN, S. Ventilation, sensible heat loss, broiler energy, and water balance under harsh environmental conditions. Poultry Science, Champaign, v. 83, n. 2, p.253-258, 2004. 